\title{
Synergistic inhibition of characteristics of liver cancer stem-like cells with a combination of sorafenib and 8-bromo-7-methoxychrysin in SMMC-7721 cell line
}

\author{
HUI ZOU ${ }^{1 *}$, XIAOZHENG CAO $^{1,2^{*}}$, QIAO XIAO ${ }^{1}$, XIFENG SHENG $^{1}$, KAIQUN REN $^{1}$, MEIFANG QUAN $^{1}$, \\ ZHENGWEI SONG ${ }^{1}$, DUO LI $^{1}$, YU ZHENG ${ }^{1}$, WENBIN ZENG ${ }^{2}$, JIANGUO CAO ${ }^{1}$ and YAOJIN PENG ${ }^{1}$ \\ ${ }^{1}$ Medical College, Hunan Normal University, Changsha, Hunan 410013; ${ }^{2}$ School of Pharmaceutical Sciences, \\ and Molecular Imaging Research Center, Central South University, Changsha, Hunan 410013, P.R. China
}

Received March 23, 2016; Accepted July 21, 2016

DOI: 10.3892/or.2016.4973

\begin{abstract}
Sorafenib, a multi-kinase inhibitor, has shown its promising antitumor effect in a series of clinical trials, and has been approved as the current standard treatment for advanced hepatocellular carcinoma (HCC). 8-Bromo-7-methoxychrysin (BrMC) is a novel chrysin synthetic analogue that has been reported to inhibit the growth of various tumor cells and possess properties for targeting liver cancer stem cells (LCSCs) . The present study investigated the synergistic targeting effects on the properties of liver cancer stem-like cells (LCSLCs) by a combination of sorafenib and BrMC in SMMC-7721 cell line. We also investigated whether this effect involves regulation of HIF-1 $\alpha$, Twist and NF- $\mathrm{kB}$ protein. We found that the sphereforming cells (SFCs) from the SMMC-7721 cells possessed the properties of LCSLCs. Sorafenib diminished the self-renewal capacity and downregulated the expression of stem cell biomarkers (CD133, CD44 and ALDH1) in a dose-dependent manner, while BrMC cooperated with sorafenib to strengthen this inhibition. Moreover, the combination of sorafenib and BrMC led to a remarkable decrease in the cellular migration and invasion, the downregulation of $\mathrm{N}$-cadherin protein and upregulation of E-cadherin protein, and increase of cell apoptosis in LCSLCs. BrMC has a remarkable antagonistic effect on the upregulation of protein expression and DNA binding activity of NF- $\mathrm{\kappa B}$ (p65) induced by sorafenib. In addition, our results indicated that the synergistic inhibition of sorafenib and BrMC on the characteristics of LCSLCs involves the downregulated expression of HIF-1 $\alpha$ and EMT regulator
\end{abstract}

Correspondence to: Dr Yaojin Peng, Medical College, Hunan Normal University, Changsha, Hunan 410013, P.R. China

E-mail: pengyj@aliyun.com

*Contributed equally

Key words: hepatocellular carcinoma, liver cancer stem-like cells, 8-bromo-7-methoxychrysin, sorafenib, synergistic inhibition, NF- $\kappa$ B, HIF-1 $\alpha$, Twist1
Twist1. Collectively, the combination therapy of sorafenib and BrMC could be a new and promising therapeutic approach in the treatment of HCC.

\section{Introduction}

Hepatocellular carcinoma (HCC) is the sixth most common malignancy and the second leading cause of cancer-related death (1). In China, the incidence of liver cancer accounts for $50 \%$ of the cases worldwide, and mortality caused by liver cancer is second only to lung cancer (2). Although there has been noticeable progress in the treatment of HCC and surgical resection have greatly improved survival in patients at very early stage, long-term survival remains unsatisfactory and many patients may develop a tumor recurrence, which is the primary cause of treatment failure. Current therapeutic strategies have failed to solve the high recurrence rate and high mortality of HCC. Therefore, it is urgent to seek new effective therapy strategies to combat HCC.

Sorafenib, a multi-kinase inhibitor, has been approved for the clinical treatment of advanced HCC and it prolongs the overall survival of HCC patients nearly 3 months (3). A number of studies have shown that sorafenib blocks tumor angiogenesis and proliferation. Mechanistically, sorafenib inhibits multiple signaling pathways including Raf-1 (or C-Raf) and B-Raf, vascular endothelial growth factor (VEGF) receptors 2 and 3, platelet-derived growth factor (PDGF) receptor, c-KIT and FMS-like tyrosine kinase 3 (FLT3) (4). In addition, sorafenib may be the only choice of systemic therapy and also represent the new first-line treatment standard for advanced HCC patients. However, clinical trials seem disappointing as a large number of patients with advanced HCC are unresponsive or acquire resistance to sorafenib. Hence, it is necessary to evaluate the effect of sorafenib in combination with other antitumor agents on HCC.

Cancer stem cells (CSCs), also termed as cancer initiating cells, is a subset of cells within tumors that are believed to initiate and maintain cancers. There is an increasing interest among researchers on the CSCs concept. To date, CSCs have been confirmed to exist in many tumors including leukemia, breast and brain cancer, glioma, pancreatic and 
liver cancer (5-11). The critical role of CSCs in tumorigenesis, tumor metastasis and resistance to anticancer therapy has also been demonstrated in HCC (12-14). Hence, targeting CSCs may be potential treatments for HCC.

8-Bromo-7-methoxychrysin (BrMC) is a novel chrysin analogue, synthesized by our team, inhibiting the growth of a variety of tumor cells. BrMC strongly inhibited the proliferation of human colon carcinoma cell line (HT-29) and human gastric cancer cell line (SGC-7901) $(15,16)$. It was also found that BrMC led to HCC cell apoptosis by stimulating the ROS production and activation of JNK (17). Our previous study demonstrated that BrMC significantly inhibited the self-renewal and tumorigenicity in nude mice of CD133-positive sphere-forming cells from hepatoma cell line SMMC-7721 in a dose-dependent manner (18). The evidence confirmed that BrMC had treatment effect to HCC and had litter impact on human embryonic liver cell line L-02 (17).

Nuclear factor- $\kappa \mathrm{B}(\mathrm{NF}-\kappa \mathrm{B})$ pathway plays an important role in many physiological and pathological processes including immunity, inflammation, cell proliferation and differentiation (19). The abnormal activation of $N F-\kappa B$ pathway can be found in many cancer cells and is also responsible for tumorigenesis and chemoresistance $(20,21)$. Furthermore, NF- $\kappa \mathrm{B}$ can be activated by a number of chemotherapeutic agents including sorafenib (22) and apoptosis inducing factor such as TNF-related apoptosis inducing ligand. Thus, this may suggest that the sorafenib-induced $\mathrm{NF}-\kappa \mathrm{B}$ activation may partially contribute to the resistance to sorafenib.

Our previous study revealed that, BrMC inhibited liver cancer stem cells (LCSCs) properties in SMMC-7721 cell lines by downregulation of Twist expression (18). The EMT-related protein twistl has been associated with early signs of metastasis following tumor hypoxia and NF- $\kappa \mathrm{B}$ activity $(23,24)$. It has been reported that chrysin (the lead compound of BrMC) effectively can downregulate the tumor hypoxia inducible factor- $1 \alpha$ (HIF-1 $\alpha$ ) protein (25). Based on the above evidence, we first looked forward with a new idea for the combination of sorafenib and BrMC. In the present study, we evaluated the inhibition of sorafenib alone and combined with BrMC on the characteristics of liver cancer stem-like cells (LCSLCs) and their potential mechanism.

\section{Materials and methods}

Chemicals. BrMC was synthesized as previously described(15). The purity was analyzed as $99.5 \%$ by HPLC. Sorafenib was purchased from the Jinan Kaien Pharmaceutical Technology Co., Ltd. (Jinan, Shandong, China).

Cell culture and reagents. Human HCC SMMC-7721 cells were purchased from the Chinese Academy Cell Bank (Shanghai, China), and were maintained in Dulbecco's modified Eagle's medium (DMEM) supplemented with $10 \%$ fetal bovine serum (FBS; Thermo Scientific, Waltham, MA, USA), $100 \mathrm{IU} / \mathrm{ml}$ penicillin $\mathrm{G}$ and $100 \mu \mathrm{g} / \mathrm{ml}$ streptomycin (Invitrogen Life Technologies, Carlsbad, CA, USA) in a humidified atmosphere containing $5 \% \mathrm{CO}_{2}$ at $37^{\circ} \mathrm{C}$. Trypsin and dimethyl sulfoxide (DMSO) were purchased from Amersco Co. (Solon, OH, USA).
Sphere formation and self-renewal assay. Parental cells were collected and washed to remove serum, and then suspended in serum-free stem cell conditional medium containing DMEM/ F12 (Gibco-Invitrogen, Carlsbad, CA, USA) supplemented with $100 \mathrm{IU} / \mathrm{ml}$ penicillin $\mathrm{G}, 100 \mu \mathrm{g} / \mathrm{ml}$ streptomycin, $20 \mathrm{ng} / \mathrm{ml}$ EGF, $10 \mathrm{ng} / \mathrm{ml}$ bFGF (both from Peprotech Inc., Rocky Hill, NJ, USA), and 1X B27 (Invitrogen). The cells were next plated in ultra-low adherence culture plates (6-wells) at a density of 5,000 cells/well kept under a humidified incubator containing $5 \% \mathrm{CO}_{2}$ at $37^{\circ} \mathrm{C}$. After 5 days of culture, sphere-forming cells (SFCs) were obtained after trypsin-EDTA digestion, and visualized in a microscope followed by cell counting. For comparing the sphere formation capability of different generation, the first generation SFCs were plated at a density of 1,000 cells/ml in ultra-low adhesion 6-well culture plates, and then to obtain the second, third and fourth generation SFCs after continuous culture.

To investigate the effects of BrMC and sorafenib on the self-renewal of SFCs, single cell suspension of the third generation SFCs was plated at a density of 1,000 cells $/ \mathrm{ml}$ in ultra-low adhesion 24-well culture plates. The different concentrations of sorafenib $(5,15$ and $45 \mu \mathrm{mol} / \mathrm{l})$ and BrMC $(5 \mu \mathrm{mol} / \mathrm{l})+$ different concentrations of sorafenib $(5,15$ and $45 \mu \mathrm{mol} / \mathrm{l})$ were added to the stem cell conditioned medium of SFCs with the control groups treated with $0.1 \%$ DMSO and BrMC ( $5 \mu \mathrm{mol} / \mathrm{l})$, respectively. The number of tumor spheroids under the Olympus IX51 inverted fluorescence microscope was counted after culturing for 5 days.

Transwell invasion assay in vitro. To detect the invasive ability of SFCs by Transwell chamber system with $8.0-\mu \mathrm{m}$ pore size polycarbonate membrane, and the lower side of the filter coated with $10 \mu \mathrm{l}$ of gelatin and the upper side coated with $10 \mu \mathrm{l}$ of Matrigel.

DMEM medium $(1.0 \mathrm{ml})$ supplemented with $10 \%$ FBS as a chemical inducer was added to the 24-well cell culture plate, and then embedded in the Transwell chamber. A total of 5,000 parent cells or SFCs were plated in the top chamber of the Transwell coated with Matrigel and treated with different concentrations of sorafenib (5, 15 and $45 \mu \mathrm{mol} / \mathrm{l})$ and BrMC $(5 \mu \mathrm{mol} / \mathrm{l})+$ different concentrations of sorafenib $(5,15$ and $45 \mu \mathrm{mol} / \mathrm{l})$ for $24 \mathrm{~h}$. The cells that had not invaded through the pores of the insert were eliminated with a sterile cotton swab and discarded. Cells invaded to the lower chamber were fixed with methanol, stained with crystal violet and counted under the optical microscope.

Scratch assay. The SFCs were treated with different concentrations of sorafenib $(5,15$ and $45 \mu \mathrm{mol} / \mathrm{l})$ and BrMC $(5 \mu \mathrm{mol} / \mathrm{l})+$ different concentrations of sorafenib $(5,15$ and $45 \mu \mathrm{mol} / \mathrm{l}$ ) for $24 \mathrm{~h}$. Then, were seeded in 6-well plates at a density of $4 \times 10^{5} /$ well in DMEM complete medium supplemented with $10 \%$ FBS. When the cells grew to $85 \%$ confluency, a wound was generated by scratching the surface of the plates in the central region with a $200 \mu 1$ pipette tip. Phosphatebuffered saline (PBS) was used for washing 2 times to remove floating cells and debris. Cells were incubated for $48 \mathrm{~h}$, and were photographed at 0,24 and $48 \mathrm{~h}$ in the same location of the wound, respectively. The number of cells in the scratch area was counted. 

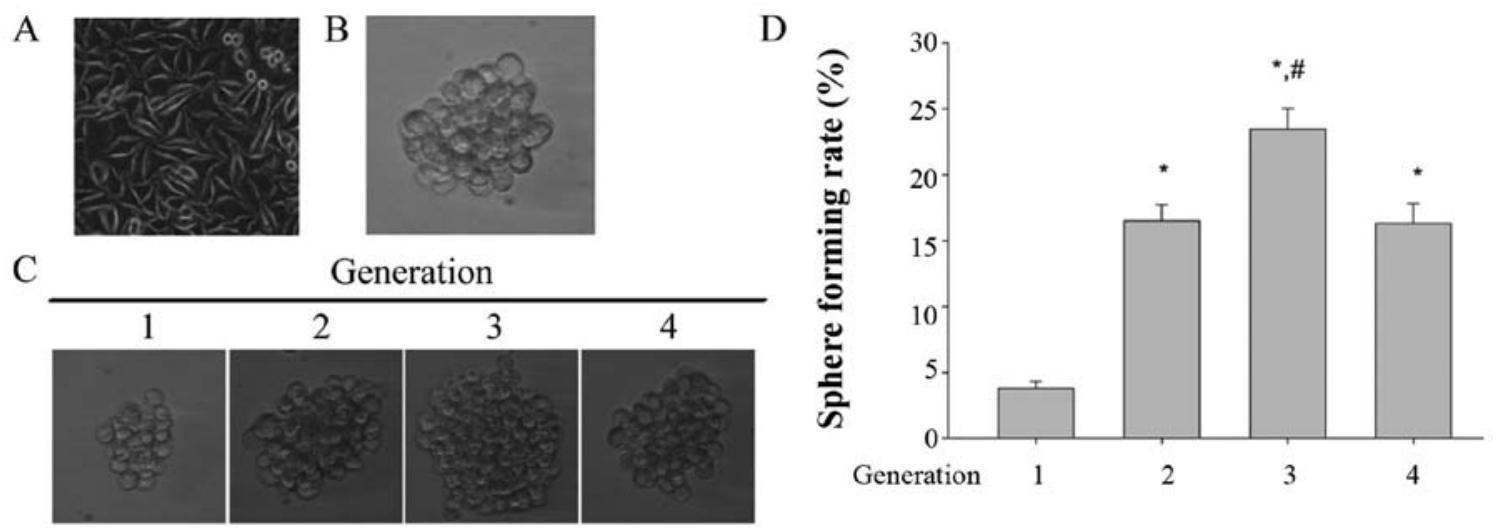

Figure 1. Sphere-forming cells (SFCs) from SMMC-7721 cells highly enriched liver cancer stem-like cells (LCSLCs). (A) Human hepatoma carcinoma cell line SMMC-7721 (parental cells) was cultured in DMEM medium. (B) The tumor spheroids from the SMMC-7721 in the stem cell culture system. (C) The different generations of SFCs. (D) The sphere forming rate of different generations of SFCs. ${ }^{*} \mathrm{P}<0.05$ compared with the first generation; ${ }^{*} \mathrm{P}<0.05$ compared with the second and fourth generations.

Apoptosis analysis by flow cytometry. Cells were stained with Annexin V-FITC apoptosis detection kit (BD Biosciences, San Jose, CA, USA). According to the manufacturer's instructions, the cells were incubated with $5 \mathrm{ml}$ of Annexin $\mathrm{V}$ and $5 \mathrm{ml}$ of propidium iodide (PI) for $15 \mathrm{~min}$ at room temperature, and then the stained cells were analyzed on a FACS flow cytometer.

Western blot analysis. Cells were washed with pre-cold PBS, and lysed in $1 \mathrm{ml}$ lysis enzyme buffer [50 mM Tris- $\mathrm{HCl}$ (pH 7.4), $150 \mathrm{mM} \mathrm{NaCl}, 0.2 \mathrm{mM}$ EDTA, $0.2 \%$ NP-40, 10\% glycerol, $1 \mathrm{M} \beta-\mathrm{Me}, 1 \mu \mathrm{g} / \mathrm{ml}$ Trasylol, $0.5 \mu \mathrm{g} / \mathrm{ml}$ leupeptin, $0.1 \mathrm{mM} 0.1 \mathrm{mM} \mathrm{Na} \mathrm{VO}_{4}, 0.5 \mathrm{mM} 4-\mathrm{NPP}, 0.5 \mathrm{mM} \mathrm{NaF}$ and protease inhibitors]. The cells were scraped and collected after incubated for $20 \mathrm{~min}$ at $4^{\circ} \mathrm{C}$. Lysates were centrifuged at $1,2000 \mathrm{rpm}$ for $15 \mathrm{~min}$ at $4^{\circ} \mathrm{C}$ to prepare whole cell extracts. Protein was separated by $10 \%$ SDS-PAGE gel after electrophoresis, and transferred to a polyvinylidene difluoride (PVDF) membrane (Millipore, Billerica, MA, USA). The membranes were detected by rabbit antibodies against Twist, HIF-1 $\alpha$ and $\mathrm{NF}-\kappa \mathrm{B}$ (p65) or mouse antibodies against CD133, CD44, ALDH1, N-cadherin, E-cadherin and $\beta$-actin, respectively.

$N F-\kappa B$ binding activity assay. The NF- $\kappa \mathrm{B}$ activity in the nuclear protein $(20 \mu \mathrm{g})$ of treated or control LCSLCs was measured using a DNA-binding ELISA kit (TransAM ${ }^{\mathrm{TM}}$ NF- $\kappa \mathrm{B}$ p65 assay; Active Motif, Carlsbad, CA, USA) according to the manufacturer's instructions. Absorbance at $405 \mathrm{~nm}$ wavelength (A405) was measured by means of an enzyme-labeling instrument (ELX-800 type; Bio-Tek, Shanghai, China).

Statistical analysis. Data are presented as the mean $\pm \mathrm{SE}$ and were analyzed by SPSS 17.0 statistical software. Multiple comparison were performed by one-way ANOVA and pair-wise comparison was performed by LSD-t method. $\mathrm{P}<0.05$ were considered to indicate a statistically significant result.

\section{Results}

Cultivation and amplification of LCSLCs from the SMMC-7721 cell line. Human HCC SMMC-7721 cell line cultured in normal condition remained as monolayer, with anchoragedependent growth (Fig. 1A, parental cells). Numerous studies confirmed that the spheres cultured in serum-free culture medium (SFM) are highly enriched for cancer stem cells (CSCs). In order to enrich LCSLCs from SMMC-7721 cell line, stem cell conditioned medium suspension culture method was used. Under these conditions, the cells grew as non-adherent, 3-dimensional sphere clusters. After 5 days of incubation, the anchorage-independent colonies were found that formed in the SMMC-7721 cell line in the case of inoculation of 2,000 cells/well (Fig. 1B).

Self-renewal is one of most important properties of cancer stem cells. To test the self-renewal ability, the tumor spheres were disperse into single-cell suspension, and then applied to multiple continuous subculture at the $1,000 / \mathrm{ml}$ of the inoculation density in the stem cell conditioned medium. Fig. 1C and D show the size of the tumor spheres and the sphere formation rate of different generations, respectively. The result showed that the tumor spheres derived from SMMC-7721 possess the ability to form spheroids, and the third generation of tumor spheroids has the maximum size of tumor spheroids and the highest sphere forming rate. These data indicated that the tumor spheroids derived from SMMC-7721 has the capacity of self-renewal and the third generation was given the strongest self-renewal capability. Therefore, the third generation tumor spheroids were regarded as the LCSLCs or the SFCs.

Characterization of LCSLCs from the SMMC-7721 cell line. To characterize the SFCs, western blot analysis was performed to test the protein expression level of these biomarkers. The results showed the higher expression level of CSC biomarkers (CD133, CD44 and ALDH1) in SFCs compared with the parental cells (PCs) (Fig. 2A).

CSCs have higher migratory and invasion capacity, which are thought to contribute to the metastasis and growth. The migration and invasion capabilities of SFCs and PCs were evaluated by scratch method and Transwell chamber invasion assay in vitro, respectively. The results demonstrated that SFCs showed stronger migration and invasion capabilities than PCs (Fig. 2B and C). CSCs are also deemed to promote metastasis through EMT characteristics correlating with the 
A

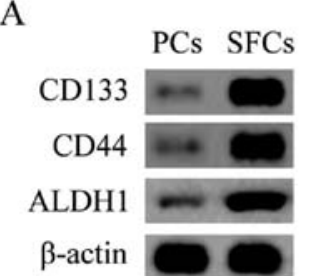

$\mathrm{C}$

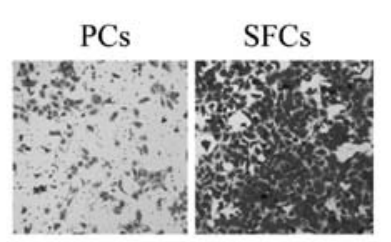

B

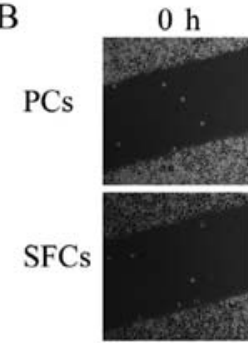

를
$\mathrm{D}$
$\mathrm{E}$

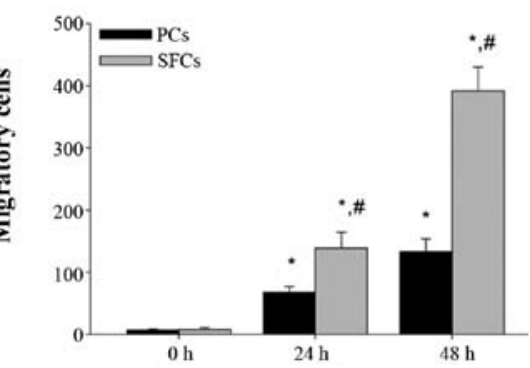

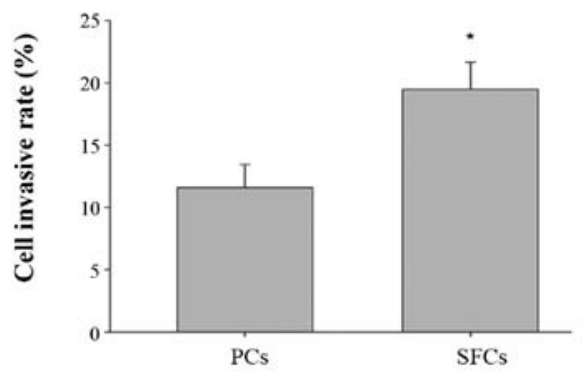

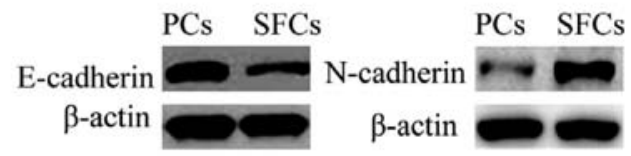

PCs

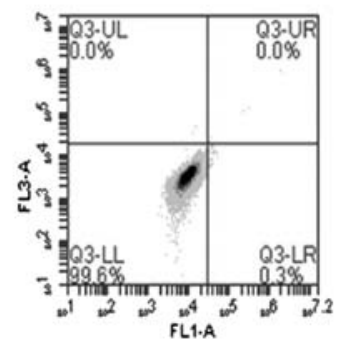

SFCs

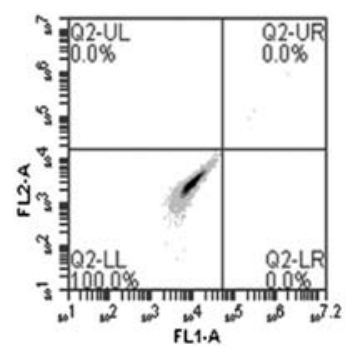

Figure 2. Identification of LCSLCs in SMMC-7721 cell line. (A) The CD133, CD44 and ALDH1 protein expression levels in SFCs and their PCs. (B) The cell migration of SFCs from SMMC-7721 cells compared with PCs. " $\mathrm{P}<0.05$ compared with $0 \mathrm{~h} ;{ }^{*} \mathrm{P}<0.05$ compared with PCs. (C) The invasion ability of SFCs compared with PCs; "P<0.05 compared with PCs. (D) The protein expression levels of N-cadherin and E-cadherin in SFCs compared with PCs. (E) The apoptotic rate of PCs and SFCs by flow cytometry.

mobility of cancer cells. We evaluated the protein expression of well-known mesenchymal phenotype cell biomarkers (N-cadherin) and epithelial phenotype cell biomarker (E-cadherin) by western blot analysis. The results showed that the relative protein levels of $\mathrm{N}$-cadherin was highly expressed in SFCs, while that of E-cadherin was low (Fig. 2D). In addition, the spontaneous apoptosis levels of SFCs and PCs were detected using Annexin V-FITC/PI. Both the spontaneous apoptosis of SFCs and PCs were $<0.5 \%$, indicating both of them have good cell activity (Fig. 2E). These results indicated that the SFCs from SMMC-7721 cells possess LCSLCs properties.

The combination of BrMC and sorafenib enhances the inhibition of self-renewal and expression of biomarkers of LCSLCs. Our previous study revealed that BrMC can inhibit the characteristic of LCSCs including proliferation, selfrenewal and invasion (17). In the present study, we investigated whether BrMC in combination with sorafenib synergistically inhibits the characteristic of LCSLCs. As shown in Fig. 3A, the treatment with BrMC $(15 \mu \mathrm{mol} / \mathrm{l})$ and sorafenib $(5,15$ and $45 \mu \mathrm{mol} / \mathrm{l})$ alone inhibited the self-renewal, while the combination treatment group showed an augmented inhibition of self-renewal. We performed western blot analyses to evaluate the expression of CD133, CD44 and ALDH1. Combined treatment with BrMC and sorafenib showed a higher reduction of the expression level of CD133, CD44 and ALDH1 than treatment with both of them alone in the LCSLCs in a dosedependent manner (Fig. 3B).
The combination of BrMC and sorafenib enhances the inhibition of migration, invasion and the expression of EMT biomarkers. Migration and invasion properties are important characteristics of CSCs, and they are highly correlated with tumor metastasis and growth. The scratch method was used to evaluate whether the combination of BrMC and sorafenib have a stronger inhibition on the migration of LCSLCs than both of them alone. The results showed that the migration was significantly suppressed in a dose-dependent manner after treatment with sorafenib for 24 and $48 \mathrm{~h}$ (Fig. 4A), and this inhibitory effect was potentiated by the combination with BrMC.

We next performed a Transwell assay to demonstrate whether the sorafenib and the combination groups affects invasion of LCSLCs. As shown in Fig. 4B, both sorafenib $(5,15$ and $45 \mu \mathrm{mol} / \mathrm{l})$ and $\mathrm{BrMC}(5 \mu \mathrm{mol} / \mathrm{l})$ inhibited the invasion of LCSLCs, and the combination group enhanced the invasion ability.

Western blot analysis was also performed to check the variety of EMT biomarkers (E-cadherin and N-cadherin) in LCSLCs treated with sorafenib $(5,15$ and $45 \mu \mathrm{mol} / \mathrm{l})$ and combined with BrMC (5 $\mu \mathrm{mol} / \mathrm{l})$. We found that sorafenib upregulated the E-cadherin, and the different concentrations of sorafenib $(5,15$ and $45 \mu \mathrm{mol} / \mathrm{l})$ combined with BrMC (5 $\mu \mathrm{mol} / \mathrm{l})$ displayed a stronger effect on this upregulation (Fig. 4C). While the treatment of sorafenib (5, 15 and $45 \mu \mathrm{mol} / \mathrm{l})$ and combination with $\operatorname{BrMC}(5 \mu \mathrm{mol} / \mathrm{l})$ led to the downregulation of $\mathrm{N}$-cadherin in LCSLCs, and the combination group also showed a stronger effect (Fig. 4D). Together, these data suggested that sorafenib $(5,15$ and $45 \mu \mathrm{mol} / \mathrm{l})$ can 
A

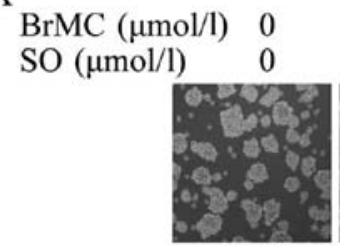

$\operatorname{BrMC}(\mu \mathrm{mol} / \mathrm{l}) 5$ SO $(\mu \mathrm{mol} / \mathrm{l})$

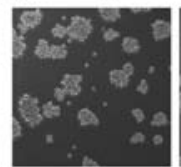

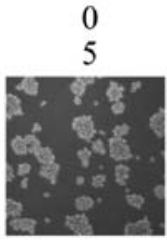

5

5

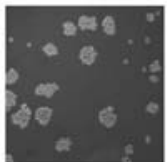

${ }_{\overline{\underline{\Xi}}}^{500}{ }^{500-} \rightleftharpoons_{\mathrm{BrMC}+\mathrm{SO}}^{\mathrm{SO}}$

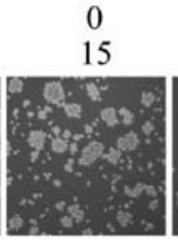

5

15

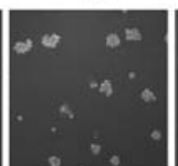

(1)

$B$

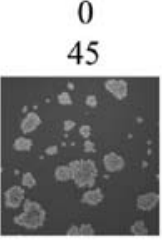

5 45

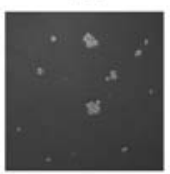

$\operatorname{BrMC}(\mu \mathrm{mol} / \mathrm{l}) 0 \quad 5 \quad 5 \quad 5 \quad 5$

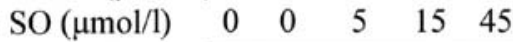
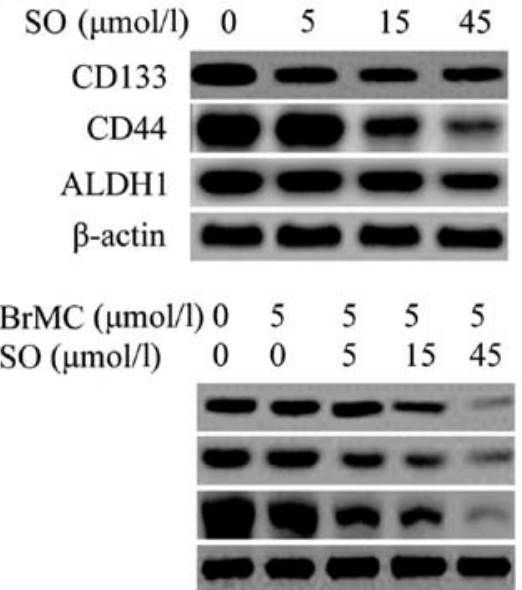

Figure 3. Inhibition of self-renewal and downregulation of CSC marker expression by sorafenib (SO) alone and combined with BrMC in SFCs derived from SMMC-7721 cells. (A) Sorafenib alone and combined with BrMC (5.0 $\mu \mathrm{mol} / 1)$ suppressed the self-renewal of SFCs. "P<0.05 compared with $0.1 \%$ DMSO; ${ }^{\#} \mathrm{P}<0.05$ compared with SO alone. (B) Sorafenib alone and combined with BrMC (5.0 $\left.\mu \mathrm{mol} / \mathrm{l}\right)$ inhibited the expression of cancer stem cell markers CD44, CD133 and ALDH1 protein in SFCs.

A
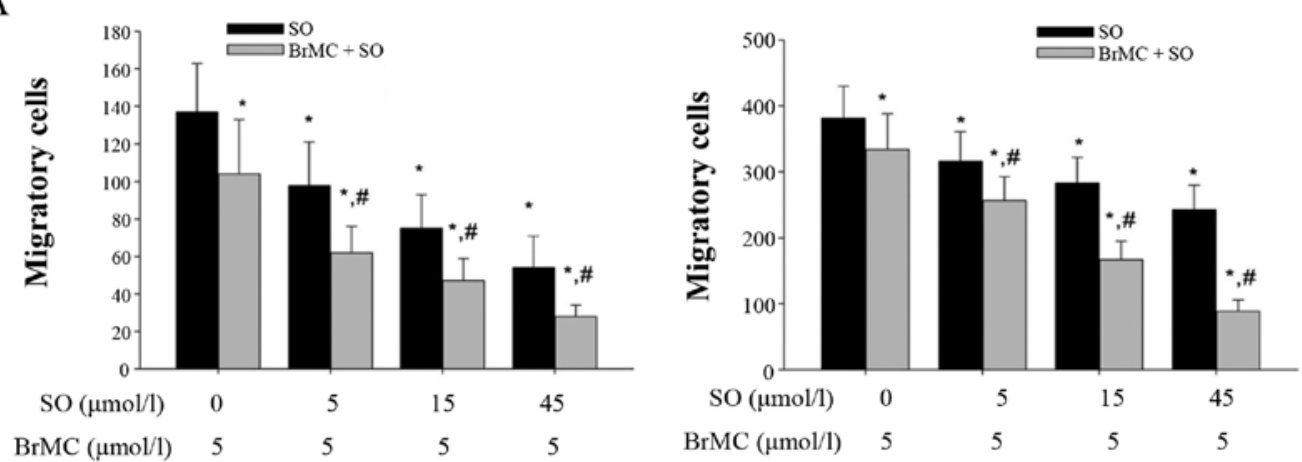

$\mathrm{B}$

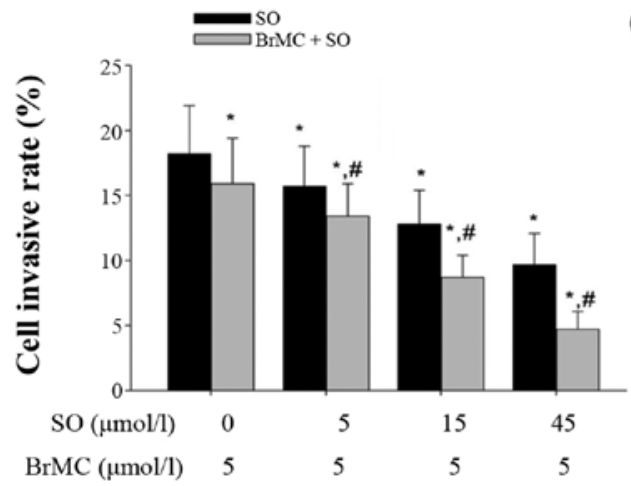

$\mathrm{C}$

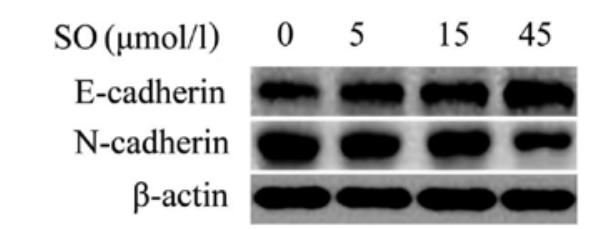

$\begin{array}{llllll}\mathrm{BrMC}(\mu \mathrm{mol} / \mathrm{l}) & 0 & 5 & 5 & 5 & 5 \\ \mathrm{SO}(\mu \mathrm{mol} / \mathrm{l}) & 0 & 0 & 5 & 15 & 45\end{array}$

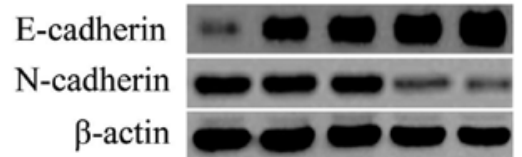

Figure 4. The effects of sorafenib alone and combined with BrMC on migration, invasion capabilities and EMT phenotype in SFCs derived from SMCC-7721 cells. (A) The inhibition ( 24 and $48 \mathrm{~h}$ ) of migratory abilities by sorafenib $(0,5,15$ and $45 \mu \mathrm{mol} / \mathrm{l})$ alone and combined with BrMC (5 $\mu \mathrm{mol} / \mathrm{l})$ in SFCs. (B) The inhibition of cell invasion abilities by sorafenib $(0,5,15$ and $45 \mu \mathrm{mol} / \mathrm{l})$ alone and combined with BrMC $(5 \mu \mathrm{mol} / 1)$ in SFCs. (C) The effect of sorafenib $(0,5$, 15 and $45 \mu \mathrm{mol} / \mathrm{l})$ alone and combined with $\mathrm{BrMC}(5 \mu \mathrm{mol} / \mathrm{l})$ on the expression of E-cadherin and $\mathrm{N}$-cadherin in $\mathrm{SFCs}$. ${ }^{*} \mathrm{P}<0.05 \mathrm{compared}$ with $0 \mathrm{~h} ;{ }^{\#} \mathrm{P}<0.05$ compared with sorafenib alone. 
$\mathrm{SO}(\mu \mathrm{mol} / \mathrm{l})$
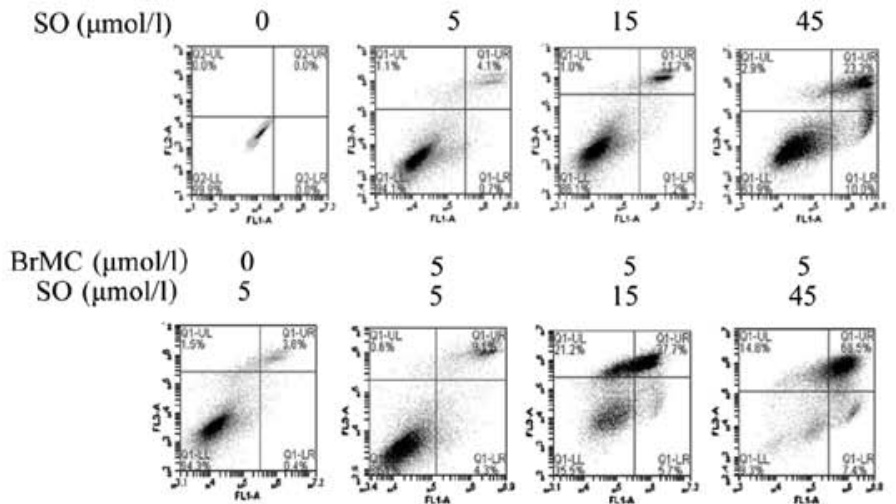

Figure 5. The effects of sorafenib (SO) $(0,5,15$ and $45 \mu \mathrm{mol} / 1)$ alone and combined with BrMC (5 $\mu$ mol/1) on the apoptosis of SFCs derived from SMCC-7721 cells. ${ }^{\mathrm{P}}<0.05$ compared with $0 \mathrm{~h} ;{ }^{*} \mathrm{P}<0.05$ compared with $\mathrm{SO}$ alone.

A

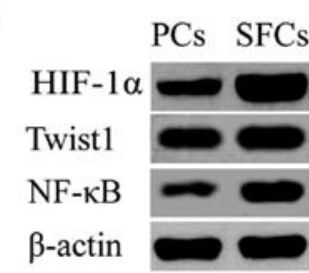

B

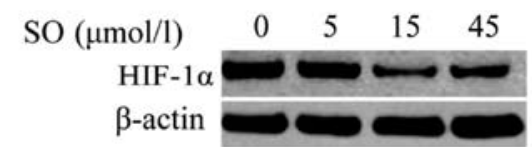

$\begin{array}{llllcc}\mathrm{BrMC}(\mu \mathrm{mol} / 1) & 0 & 5 & 5 & 5 & 5 \\ \mathrm{SO}(\mu \mathrm{mol} / 1) & 0 & 0 & 5 & 15 & 45\end{array}$

HIF-1 $\alpha$

$\beta$-actin

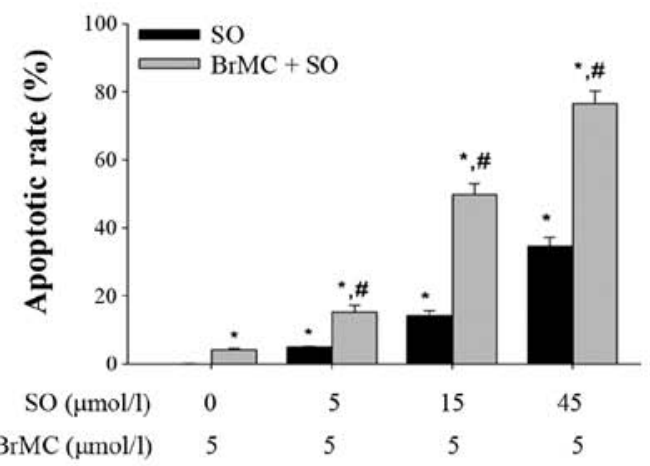

$\mathrm{C}$

$\mathrm{D}$
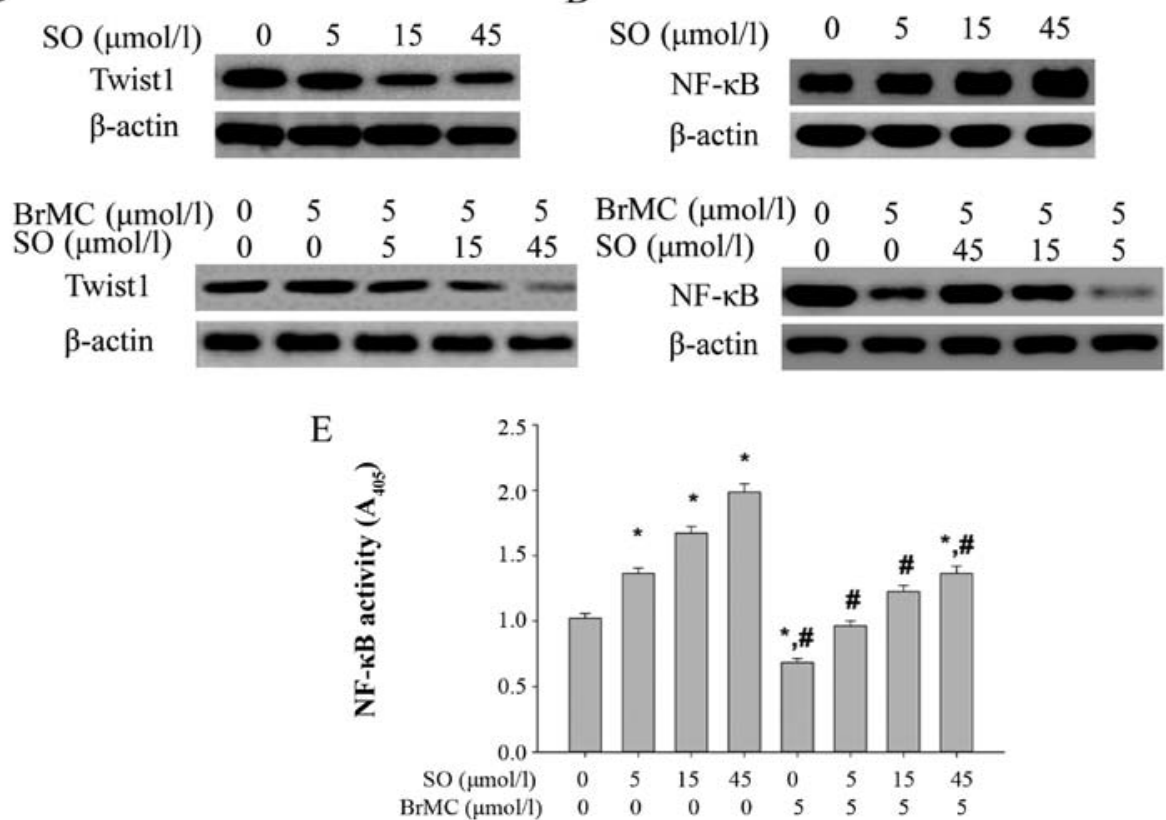

Figure 6. The expression levels of HIF-1 $\alpha$, Twist1 and NF- $\kappa$ B in SFCs. (A) The expression levels of HIF-1 $\alpha$, Twist1 and NF- $\kappa$ B in SFCs compared with that in PCs. (B) The downregulation of HIF- $1 \alpha$ by sorafenib $(0,5,15$ and $45 \mu \mathrm{mol} / 1)$ alone and combined with BrMC (5 $\mu$ mol/1). (C) The downregulation of Twist1 by sorafenib $(0,5,15$ and $45 \mu \mathrm{mol} / 1)$ alone and combined with BrMC (5 $\mu \mathrm{mol} / 1)$. (D) The effects of sorafenib (0, 5,15 and $45 \mu \mathrm{mol} / 1)$ alone and combined with BrMC $(5 \mu \mathrm{mol} / 1)$ on the expression levels of NF- $\kappa \mathrm{B}$ in SFCs. ${ }^{*} \mathrm{P}<0.05$ compared with $0 \mathrm{~h}$; ${ }^{*} \mathrm{P}<0.05$ compared with sorafenib alone. (E) The effects of sorafenib $(0,5,15$ and $45 \mu \mathrm{mol} / 1)$ alone and combined with BrMC $(5 \mu \mathrm{mol} / 1)$ on the NF- $\kappa \mathrm{B}$ DNA binding activity measured using a ELISA kit. ${ }^{*} \mathrm{P}<0.05 \mathrm{compared}$ with $0.1 \%$ DMSO; ${ }^{\#} \mathrm{P}<0.05$ compared with sorafenib alone.

effectively inhibit EMT in LCSLCs, and BrMC can cooperate with sorafenib to enhance the inhibition of EMT in a dose-dependent manner.

Synergistic apoptosis induction in LCSLCs by sorafenib and $B r M C$. To study whether sorafenib and BrMC synergistically induce apoptosis of LCSLCs, Annexin V-FITC/PI and flow cytometric analysis were used. The results showed that BrMC $(5 \mu \mathrm{mol} / \mathrm{l})$ with the different concentrations of sorafenib $(5,15$ and $45 \mu \mathrm{mol} / \mathrm{l}$ ) has a synergistic induction to cell apoptosis activity of LCSLCs compared with the corresponding concentration of sorafenib $(5,15$ and $45 \mu \mathrm{mol} / \mathrm{l})$ group (Fig. 5). 
Synergistic downregulation of the expression of HIF-1 $\alpha$, Twist 1 and NF- $\kappa B$ in LCSLCs by sorafenib and BrMC. Hypoxia is one of the fundamental biological phenomena that plays a key role in the development and aggressiveness of a wide variety of cancers including HCC $(26,27)$. The homeostatic response to hypoxia is predominantly mediated by the transcription factor HIF-1 $\alpha$ which has been widely accepted to be associated with tumor invasion, metastasis and treatment resistance. Transcription factor Twist1 was proved to be a critical EMT molecule.

To evaluate the effect on the protein expression of HIF-1 $\alpha$, Twist1 and NF- $\mathrm{kB}$ in LCSLCs and PCs, western blot analysis were performed. Fig. 6A shows the higher expression of HIF-1 $\alpha$ in LCSLCs than PCs, and sorafenib downregulated the expression of HIF- $1 \alpha$ and BrMC collaborated with sorafenib to reduce the HIF-1 $\alpha$ protein level in LCSLCs. The same function on the expression of Twist1 was observed (Fig. 6B).

The expression level of NF- $\kappa \mathrm{B}$ (p65) in LCSLCs was higher than that in PCs as shown in Fig. 6C. Previous study reported that sorafenib can strongly induce the activation of $N F-\kappa B$ signaling pathway (22), which was also verified in the present study. The increased expression level of NF- $\kappa B$ was observed in LCSLCs treated with different concentrations of sorafenib (5, 15 and $45 \mu \mathrm{mol} / \mathrm{l})$. Instead, BrMC showed strongly antagonistic action on the upregulation of NF- $\kappa B$ caused by sorafenib (Fig. 6D). To further examine the effect of sorafenib alone and the combination group on the NF- $\mathrm{KB}$ activation, the NF- $\mathrm{BB}$ activity assay was performed by use of a DNA-binding ELISA kit. The results showed that sorafenib significantly increased the DNA binding activity for NF- $\mathrm{KB}$ in a dose-depentent manner, while remarkably decreased NF- $\kappa \mathrm{B}$ activation was observed in the combination group (Fig. 6E).

\section{Discussion}

Recent findings support the concept that cancer stem cells (CSCs) possess the ability to initiate tumor formation, selfrenewal and resist chemotherapeutic drugs, thereby causing relapse of the tumor. Targeted therapy of CSCs recommend new strategies and approaches for cancer treatment. Accumulating evidence has demonstrated the existence of CSCs in hepatocellular carcinoma (HCC) $(11,28-30)$.

Although a number of studies have reported the separation of CSCs, the enrichment, isolation and identification of CSCs remain priorities for development of novel cancer therapeutic strategies. In the present study, we employed suspension culture method in ultra-low adherence plates with serum-free stem cell conditional medium to obtain SFCs. CD133 and CD44 have been widely applied to isolate and characterize the CSCs in many solid tumors $(31,32)$. ALDH1 was also recommended as marker in several types of cancers including HCC (33). The combination of multiple markers was used to improve the specificity of LCSC markers by many researches. Our findings clearly showed that the expression levels of CD133, CD44 and ALDH1 in SFCs were significantly higher than that in PCs. It was also found that SFCs from the SMCC-7721 cells exhibited superactive self-renewal capacity, higher migration and invasion capacity and EMT. Based on above-mentioned data, SFCs from the SMCC-7721 cells was identified as LCSLCs.
Recently, the unstable efficacy of sorafenib has raised concern among researchers, and 'sorafenib resistance' has become a hot topic to describe the impaired efficacy of sorafenib, particularly for patients with advanced HCC. EMT process and microenvironment in HCC were reported responsible for the drug resistance of sorafenib. It is also believed that resistance of HCC to sorafenib may be explained by LCSCs. In order to improve the impaired efficacy caused by sorafenib and resistance in advanced HCC, drugs combination is a promising direction. In the present study, we found that sorafenib suppressed the properties of LCSLCs including self-renewal, EMT, cell migration and invasion in vitro, while sorafenib combined with BrMC achieve efficient inhibition on these properties. Regarding the molecular mechanism, the combination of sorafenib and BrMC dose-dependently suppressed the expression of CD133, CD44 and ALDH1, which was related to LCSCs characteristics, and also reduced expression level of the EMT-associated key protein twist1.

The hypoxic tumor microenvironment has been shown to be associated with cancer progression. Hypoxia can promote the stem-like properties (34). HIF-1 $\alpha$ is a key hypoxia-regulatory protein involved in the regulation of several genes such as erythropoietin (EPO) and VEGF which contribute to restoration of oxygen homeostasis. HIF-1 $\alpha$ also plays an important role in the acquirement of drug-resistance against chemotherapeutic agents and correlates with the reduced rate of the patients survival (35-37). In the present study, we found that sorafenib in combination with BrMC synergistically inhibited the expression of HIF-1 $\alpha$ protein. Rausch et al (22) reported that the drug resistance of sorafenib on CSCs may result from the activation of NF- $\mathrm{kB}$ signal pathway induced by sorafenib. We also found BrMC strongly antagonized the upregulation of NF- $\mathrm{KB}$ protein and the increase of DNA binding activity of NF- $\kappa \mathrm{B}$ caused by sorafenib. Moreover, the combination of sorafenib and BrMC enhanced the apoptosis induced by sorafenib.

Collectively, we report for the first time the synergistic action of sorafenib and BrMC on HCC and its potential mechanism. Our results provide evidence that the combination of sorafenib and BrMC may be an attractive alternative for the treatment of HCC.

\section{Acknowledgements}

The present study was financially supported by grants from the National Natural Science Foundation of China (nos. 81172375 and 31400311), the Program for Excellent Talents of Hunan Normal University (no. ET1508), the Key Project of Administration of Traditional Chinese Medicine of Hunan Province (no. 201539), the Project of Hunan Provincial Natural Science Foundation (no. 13JJ3061), the Science and Technology Planning Project of Hunan Province (no. 2015SK20324) and the Construct Program of the Key Discipline of Basic Medicine in Hunan Province.

\section{References}

1. Stewart BW and Wild CP (eds): World Cancer Report 2014. International Agency for Research on Cancer (IARC), 2014.

2. Zuo TT, Zheng RS, Zhang SW, Zeng HM and Chen WQ: Incidence and mortality of liver cancer in China in 2011. Chin J Cancer 34: 508-513, 2015. 
3. Llovet JM, Ricci S, Mazzaferro V, Hilgard P, Gane E, Blanc JF, de Oliveira AC, Santoro A, Raoul JL, Forner A, et al; SHARP Investigators Study Group: Sorafenib in advanced hepatocellular carcinoma. N Engl J Med 359: 378-390, 2008.

4. Keating GM and Santoro A: Sorafenib: A review of its use in advanced hepatocellular carcinoma. Drugs 69: 223-240, 2009.

5. Bonnet D and Dick JE: Human acute myeloid leukemia is organized as a hierarchy that originates from a primitive hematopoietic cell. Nat Med 3: 730-737, 1997.

6. Al-Hajj M, Wicha MS, Benito-Hernandez A, Morrison SJ and Clarke MF: Prospective identification of tumorigenic breast cancer cells. Proc Natl Acad Sci USA 100: 3983-3988, 2003.

7. Kim Y, Wu Q, Hamerlik P, Hitomi M, Sloan AE, Barnett GH, Weil RJ, Leahy P, Hjelmeland AB and Rich JN: Aptamer identification of brain tumor-initiating cells. Cancer Res 73: 4923-4936, 2013.

8. Ignatova TN, Kukekov VG, Laywell ED, Suslov ON, Vrionis FD and Steindler DA. Human cortical glial tumors contain neural stem-like cells expressing astroglial and neuronal markers in vitro. Glia 39: 193-206, 2002.

9. Yu SC, Ping YF, Yi L, Zhou ZH, Chen JH, Yao XH, Gao L, Wang JM and Bian XW: Isolation and characterization of cancer stem cells from a human glioblastoma cell line U87. Cancer Lett 265: 124-134, 2008.

10. Li C, Heidt DG, Dalerba P, Burant CF, Zhang L, Adsay V, Wicha M, Clarke MF and Simeone DM: Identification of pancreatic cancer stem cells. Cancer Res 67: 1030-1037, 2007.

11. Gedaly R, Galuppo R, Daily MF, Shah M, Maynard E, Chen C, Zhang X, Esser KA, Cohen DA, Evers BM, et al: Targeting the $\mathrm{Wnt} / \beta$-catenin signaling pathway in liver cancer stem cells and hepatocellular carcinoma cell lines with FH535. PLoS One 9: e99272, 2014.

12. Nagano H, Ishii H, Marubashi S, Haraguchi N, Eguchi H, Doki Y and Mori M: Novel therapeutic target for cancer stem cells in hepatocellular carcinoma. J Hepatobiliary Pancreat Sci 19: 600-605, 2012

13. Li S and Li Q: Cancer stem cells and tumor metastasis (Review). Int J Oncol 44: 1806-1812, 2014.

14. Oishi N, Yamashita T and Kaneko S: Molecular biology of liver cancer stem cells. Liver Cancer 3: 71-84, 2014.

15. Zheng X, Meng WD, Xu YY, Cao JG and Qing FL: Synthesis and anticancer effect of chrysin derivatives. Bioorg Med Chem Lett 13: 881-884, 2003.

16. Xiang HL, Zheng $X$ and Cao JG: Induction of apoptosis of human gastric carcinoma SGC-790 cell line by 8-bromo-7mehoxychrysin. Zhongguo Yaolixue Tongbao 24: 1370-1372, 2008.

17. Yang XH, Zheng $X$, Cao JG, Xiang HL, Liu F and Lv Y: 8-Bromo-7-methoxychrysin-induced apoptosis of hepatocellular carcinoma cells involves ROS and JNK. World J Gastroenterol 16 3385-3393, 2010

18. Ren KQ, Cao XZ, Liu ZH, Guo H, Quan MF, Liu F, Jiang L, Xiang HL, Deng XY and Cao JG: 8-bromo-5-hydroxy-7methoxychrysin targeting for inhibition of the properties of liver cancer stem cells by modulation of Twist signaling. Int J Oncol 43: 1719-1729, 2013

19. Perkins ND: The diverse and complex roles of NF- $\kappa B$ subunits in cancer. Nat Rev Cancer 12: 121-132, 2012.

20. Chandler NM, Canete JJ and Callery MP: Increased expression of NF- $\kappa \mathrm{B}$ subunits in human pancreatic cancer cells. J Surg Res 118: 9-14, 2004.

21. Li F and Sethi G: Targeting transcription factor NF-kappaB to overcome chemoresistance and radioresistance in cancer therapy. Biochim Biophys Acta 1805: 167-180, 2010.
22. Rausch V, Liu L, Kallifatidis G, Baumann B, Mattern J, Gladkich J, Wirth T, Schemmer P, Büchler MW, Zöller M, et al: Synergistic activity of sorafenib and sulforaphane abolishes pancreatic cancer stem cell characteristics. Cancer Res 70: 5004-5013, 2010.

23. Hill RP, Marie-Egyptienne DT and Hedley DW: Cancer stem cells, hypoxia and metastasis. Semin Radiat Oncol 19: 106-111, 2009.

24. Huber MA, Azoitei N, Baumann B, Grünert S, Sommer A, Pehamberger $\mathrm{H}$, Kraut N, Beug $\mathrm{H}$ and Wirth T: NF-kappaB is essential for epithelial-mesenchymal transition and metastasis in a model of breast cancer progression. J Clin Invest 114: 569-581, 2004.

25. Fu B, Xue J, Li Z, Shi X, Jiang BH and Fang J: Chrysin inhibits expression of hypoxia-inducible factor- $1 \alpha$ through reducing hypoxia-inducible factor- $1 \alpha$ stability and inhibiting its protein synthesis. Mol Cancer Ther 6: 220-226, 2007.

26. Wilson WR and Hay MP: Targeting hypoxia in cancer therapy. Nat Rev Cancer 11: 393-410, 2011.

27. Wong CC, Kai AK and Ng IO: The impact of hypoxia in hepatocellular carcinoma metastasis. Front Med 8: 33-41, 2014.

28. Ma S, Chan KW, Hu L, Lee TK, Wo JY, Ng IO, Zheng BJ and Guan XY: Identification and characterization of tumorigenic liver cancer stem/progenitor cells. Gastroenterology 132: 2542-2556, 2007.

29. Mikhail S and He AR: Liver cancer stem cells. Int J Hepatol 2011: 486954, 2011.

30. Ji J and Wang XW: Clinical implications of cancer stem cell biology in hepatocellular carcinoma. Semin Oncol 39: 461-472, 2012.

31. Zhu CP, Wang AQ, Zhang HH, Wan XS, Yang XB, Chen SG and Zhao HT: Research progress and prospects of markers for liver cancer stem cells. World J Gastroenterol 21: 12190-12196, 2015.

32. Zhu Z, Hao X, Yan M, Yao M, Ge C, Gu J and Li J: Cancer stem/progenitor cells are highly enriched in $\mathrm{CD} 133^{+} \mathrm{CD} 44^{+}$ population in hepatocellular carcinoma. Int J Cancer 126: 20672078, 2010.

33. Ma S, Chan KW, Lee TK, Tang KH, Wo JY, Zheng BJ and Guan XY: Aldehyde dehydrogenase discriminates the CD133 liver cancer stem cell populations. Mol Cancer Res 6: 1146-1153, 2008.

34. Wu CP, Du HD, Gong HL, Li DW, Tao L, Tian J and Zhou L: Hypoxia promotes stem-like properties of laryngeal cancer cell lines by increasing the $\mathrm{CD} 133^{+}$stem cell fraction. Int $\mathrm{J}$ Oncol 44: 1652-1660, 2014.

35. Bos R, van der Groep P, Greijer AE, Shvarts A, Meijer S, Pinedo HM, Semenza GL, van Diest PJ and van der Wall E: Levels of hypoxia-inducible factor-1alpha independently predict prognosis in patients with lymph node negative breast carcinoma. Cancer 97: 1573-1581, 2003.

36. Gruber G, Greiner RH, Hlushchuk R, Aebersold DM, Altermatt HJ, Berclaz G and Djonov V: Hypoxia-inducible factor 1 alpha in high-risk breast cancer: An independent prognostic parameter? Breast Cancer Res 6: R191-R198, 2004.

37. Kurokawa T, Miyamoto M, Kato K, Cho Y, Kawarada Y, Hida Y, Shinohara T, Itoh T, Okushiba S, Kondo S, et al: Overexpression of hypoxia-inducible-factor 1alpha(HIF-1alpha) in oesophageal squamous cell carcinoma correlates with lymph node metastasis and pathologic stage. Br J Cancer 89: 1042-1047, 2003. 